\title{
Study on the Translation of Clothing Names in A Dream of Red mansions based on its English and French Versions
}

\author{
Zhe Yuan \\ Wuhan Textile University, Wuhan, 430073, China \\ Email: pauline_2005@163.com
}

Keywords: English version, French version, A Dream of Red mansions, Translation of clothing names

\begin{abstract}
This paper researches on the translation of clothing names in two versions of $A$ Dream of Red Mansions. One is the French version Le rêve dans le pavillon rouge translated by Chinese French translator Li Zhihua and his wife Jacque, another one is the English version A Dream of Red mansions translated by Chinese translator Yang Xianyi and his wife Dai Naidie. This paper mainly discusses and compares the different translation choices of the same clothing name in these two versions.
\end{abstract}

\section{Introduction}

A Dream of Red mansions was written by Cao Xueqin, a Chinese writer in the Qing Dynasty. It is one of the four masterpieces of Chinese classics, with the other three books as Journey to the West, The Water Margin and The Romance of the Three Kingdoms. Because of its remarkable status in Chinese literature, the "Redology" has vigorously developed in China. However, the translation research of it is lagging behind. For example, so far, there are only two English versions. One of it was translated by Chinese translator Yang Xianyi and his wife Dai Naidie, and we refer it as Yang's translation for short. Another French version was translated by Chinese French translator Li Zhihua and his wife Jacque, which was not finished until 1981. We refer this one as Li's translation for short.

\section{The translation of clothing names in two versions}

A Dream of Red Mansions is a collection of Chinese traditional culture, which contains almost all aspects of Chinese traditional culture, such as clothing, food, tea, wine and architecture culture, etc. [1] And clothing culture is an important part. A large number of Chinese traditional clothing names have appeared in this book and have been described in detail.44 of the first 80 chapters of the book have mentioned clothing or jewelry for 173 times. [2] Actually, this is a great challenge for translators for they need to use appropriate methods to translate these clothing names which have special Chinese connotation. [3] Because most of the clothing names have no corresponding translation in western language, the translators have to make up for the cultural loss in different language only by selecting the appropriate corresponding translation according to its context meaning.

Based on the translation of clothing names, this paper makes a comparative analysis of Yang's and Li's translation choice for expressing the meaning of clothing names in original text. Because there are many Chinese clothing names in the Manchu period, this article selects several representative clothing names to analyze.

Pao: a kind of long garments with interlayer and cotton inside. It had been a formal dress in the Qing Dynasty.

In chapter one: Wu Mao Xing Pao

Yang's: Then came a large sedan-chair in which was seated an official in a black gauze cap and red robe...... 
Li's: ...puis apparat un grand palanquin, dans lequel était porté un mandrain vêtu du bonnet de crêpe noir et de la robe de satin écarlate.

In chapter three: Da Hong Jian Xiu Pao

Yang's: His red archer's jacket embroidered with golden butterflies and flowers, was tied with a coloured tasseled palace sash.

Li's: ...vêtu d'une robe à manches dites d'archer de satin rouge vif brodé, en filé d'or à double nuance, de pavillons butinant des fleurs... (manches d'archer: manches serrées au poignet, caractéristiques du costume des guerriers, par opposition à celles des mandarins civils qui étaient larges et flottantes. )

In chapter fifteen: Jiang Ya Hai Shui Wu Zhua Bai Mang Pao

Yang's: ...... a white robe embroidered with zigzag wave patterns and five-clawed dragons.

Li's: II était vêtu d'une robe blanche, décorée des neuf dragons à cinq griffes s’ébattant parmi les ondes de la mer.

In Yang's translation, Pao was translated as “robe” and “jacket”. In English, jacket means a short coat with sleeves. Obviously, the translation is unfaithful to the original connotation of Pao. However, in English, robe means a long loose garment worn for official or ceremonial occasions. And it is faithful to the original connotation of Pao. In Li's translation, Pao was mainly translated as "robe". By the way, in French, it means vêtement ample, long et distinctif. Li's translation is basically faithful to the original text, so he made the right translation choice. It is worth noting that in the two translations, the clothing name "Jian Xiu" was all translated as "archer". [4] But it has not been explained in Yang's translation which would make readers confused. Li's translation explained this word, which means the narrow sleeves. Although the explanation is not that complete or accurate, it also shows the translator's attempt to convey the information of the original text as much as possible.

Gua: Gua is a kind of double-breasted dress in Qing Dynasty which has round collar and neat sleeves. And it is divided into long Gua and short Gua. The clothing name Gua appears in this book for many times.

In chapter three: Wo Duan Pai Sui Gua

Yang's: Over this he wore a turquoise fringed coat of Japanese satin with a raised pattern of flower in eight bunches.

Li's: Sa veste était faite de satin dit du pays des Nains, de couleur vert de roche, brodéen relief de huit grands cercle, contenant chacun quatre caractères d'heureux augure tracés en écriture sigillaire.

Here, Gua has the meaning of long gown and ceremony gown. In Yang's translation, it was translated as "coat", which did not illustrate the context meaning of Gua. In Li's translation, it was translated as "veste", which did not illustrate the context meaning of Gua either. So neither of the two versions has expressed the connotation of Gua with Chinese characteristics.

In chapter eight: Da Hong Yu Duan Dui Jin Gua Zi

Yang's: Baoyu saw that she was wearing a crimson calmet cloak which buttoned in front.

Li's: Le frérot Jade remarqua qu'elle était couverte d'une mante à revers droits de serge écarlate.

Here, Gua Zi means a long jacket for people to wear outside and keep warm. In Li's translation, Gua Zi was translated as "cloak" which has the meaning of sleeveless outer garment. Although Li added the meaning of double-breasted in the translation, it was still inaccurate. In Li's translation, Gua Zi was translated as "mante". Actually, in French, "mante" means woman cloak in old times. So Li's translation is not faithful to the original text either.

In chapter three: Wu Cai Ke Si Shi Qing Yin Shu Gua

Yang's: Her turquoise cape, lined with white squirrel was inset with designs in coloured silk.

Li's: ... et couverte d'une veste vert de roche, à motifs pentachromes, de soie ajourée, et doublée d'hermine.

Here, Gua refers to a kind of loose gown worn outside the coat by women. In Yang's translation, it was translated as "cape". Normally, people always wear cape to go outside. So the translation is not accurate. In Li's translation, it was also translated as "veste”, so Li's translation is not faithful to the original text. 
In chapter fifty: Zi Rong Jie Gua

Yang's: As she was speaking, Xifeng, in a purple woolen gown, made a smiling entrance.

Li's: A peine avait-elle prononcé ces mots qu'apparut brusquement Grande Sœur Phénix, enveloppée d'une cape d'astrakan noir.

Here, in Yang's translation, it was translated as "gown". In English, people can wear gown when they attend ceremony. So, readers could be confused because in this text the person who wears "gown" is Wang Xifeng. In addition, there is no ceremony in this context. In Li's translation, it was translated as "cape”. Readers could imagine Wang Xifeng wear a cape on her shoulders. So it is understandable to readers.

In conclusion, Gua was translated as "coat”, "cloak”, “cape” and "gown” in Yang's translation; while in Li's translation it was translated as "vested", "mante" and "cape”. Therefore, we could see that translators are trying to find the appropriate equivalent words to translate the clothing name according to the actual situation.

\section{Ao:}

In chapter sixty-three: Da Hong Mian Sha Xiao Ao Zi

Yang's: Baoyu himself stripped down to a scarlet linen jacket.

Li's: Quant au frérot Jade, la courte veste qu'il avait également gardé sur lui était faite de crêpe d'un rouge écarlate, et laissait voir à découvert...

Here, Ao refers to Jia Baoyu's home dress after getting up in the morning. Hence, in these two translations, "jacket” or "veste” could not convey the context meaning.

In chapter seventy: Hui Shu Ao Zi

Yang's: Baoyu draped his squirrel-fur jacket over his shoulders.

Li's: A ces mots, le jeune garçon enfila précipitamment une robe doublée de petit-gris.

Here, in the original text, the verb in this sentence is “披”(which means drape). So, “jacket” in Yang's translation is more fitting than "robe” in Li's translation.

In chapter three: Yin Hong Sa Hua Ban Jiu Da Ao

Yang's: His coat of a flower pattern on a bright red grouned not new.

Li's: Il était vêtu d’une longue robe mi-usée, à décor de fleurs éparses.

Here, in the original text, Jia Baoyu is taking off his formal suit for putting on casual cloth. So in Yang's translation, Ao was translated as "coat" here same as the translation of Gua in the previous translation, and it did not cause ambiguity. But Li's translation of Ao here did.

In chapter three: Da Hong Yang Duan Zhai Ken Ao

Yang's: His close-fitting red satin jacket was embroidered with gold butterflies and flowers.

Li's: Elle était vêtue d'une courte tunique, étroitement moulée au corps, de satin nuagé écarlate, où se dessinaient en filé d'or les cent papillons butinant des corolles.

Here, in the original context, Wang Xifeng appears in the book for the first time.

As one of the key figures in this book, the author Cao Xueqin is very careful in describing her. In Yang's translation, Ao was translated as the normal word "jacket" which weakened the important identity of Wang Xifeng. However, in Li's translation, Ao was translated as "tunique". In French, "tunique" refers to a kind of long dress with loose linings worn by ancient Greece and Romans. In comparison, Li's translation is more faithful to the original text.

In chapter forty: Da Hong Mian Sha Ao Zi

Yang's: Xifeng promptly showed them the lapel of the red gauze tunic she was wearing...

Li's: Grande Sœur Phénix, s’empressa d'exhiber l'envers de la robe de gaze écarlate, doublée d'ouate de soie, qu'elle portait ce jour-là.

Here, in Yang's translation, Ao was translated as "tunic" (which means leeveless Top), and it did not accurately convey the meaning of original text. But Li's translation did.

In Yang's translation, Ao was translated into "jacket”, “coat” and "tunic”. In Li's translation, Ao was translated into "veste", "robe" and "tunique". Through analysis, it is found that there are more or less errors in their translating correspondence with the original text, and there is no complete equivalence in the target language. 


\section{Conclusion}

Because of the similar life and educational background and the purpose of translation, the two translators all tried to accurately translate the names and features of the Chinese traditional clothes in A Dream of Red Mansions. [5]Two translators tried their best to convey the cultural characteristics of the original text and find the corresponding vocabulary. Although some translations do not fully conform to the meaning of the original text, it is undeniable that the two translators have done their best to transmit cultural information in the global context. The translation has a rich reference value, and these two translators are so important for spreading A Dream of Red Mansions in the West. From my perspective, whether it is English or French, if we insist on finding a word in the Western vocabulary to correspond to the original text, it would cause ambiguity or be inaccurate. In today's globalized world, China's cultural status has developed a lot. The western society's understanding of China has also developed. For these clothing names with distinctive Chinese traditional cultural meaning, it can be transliterate directly to Pao, Gua and Ao, and then briefly explained at the end of the article. In this way, it can not only avoid incorrect translation, but also inspire Western readers to further understand Chinese clothes culture.

\section{Acknowledgements}

*This paper is the research project of humanities and social science in education department of Hubei, "The comparative study on the English and French translated edition of A Dream of Red Mansions” (project number: 17Q090), The project of Wuhan Textile University, “A comparative study on the English and French translated edition of A Dream of Red Mansions"(project number: 173019), and The project of Wuhan Textile University(project number: 163092)

\section{References}

[1] Li Tche-houa \& Jacqueline Alézas, Le Rêve dans le pavillon rouge [I][II], Paris: Gallimard, 1981.

[2] YANG HY, YANG G. A Dream of Red Mansions [M]. Beijing: Foreign Language Pres, 1978.

[3] Lei Yin, Biography of Yang Xianyi[M]. Ming Pao Publications Ltd. 2007

[4] Li Shiwei, The Translation Strategies of French version of The Dream of the Red Chamber [J]. Study Commentary of A Dream of Red Mansions. 2013.

[5] Han Zhonghua, Comments on Yang\&Gladys’ English Version of a Dream of Red Mansions [J]. Study Commentary of A Dream of Red Mansions. 1986 (3). 